\title{
Portscape tourism in Japan: diversified and sustainable port space function
}

\author{
H. Kato \\ Graduate School of International Media, \\ Communication and Tourism Studies, Hokkaido University, Japan
}

\begin{abstract}
Portscape tourism in typical Japanese urban ports was analysed to reveal what kinds of resources were used for sustainable tourism in port spaces. According to the government policy so-called "Port Renaissance 21", ports should diversify port functions by introducing life-related roles as well as duties for cargo distribution and industrial base into port spaces. 5 ports of different types were selected as case studies to identify tourist attractions and resources in depth, and all of them were visited on site. This study reveals that in many ports the number of people who visit them as tourists exceeds the number of passengers who use them as traffic nodes. This study confirms that each case study utilises its own local resources as tourist attractions which include a) viewing spots on sea, b) drifting sea ice in port space, and c) a sea forest converted from a waste disposal site. Collaboration between each local port residents and people who live outside the regions is a key factor to gain ground in finding, preserving and using local resources as tourist attractions. The results show that many Japanese ports have been diversifying their functions to fulfil their regional expectations by using local resources, except that they wait to be fully exploited for sustainable port tourism.
\end{abstract}

Keywords: local resource, tourist attractions, Port Renaissance 21, heritage, viewing spot, breakwater, drifting sea ice, life-related, case study, waterfront.

\section{Introduction}

Portscape is defined in this paper as the overall visual impression of the built environment and nature scenery at ports. Ports and harbours have long been playing a vital role as venues for goods exchange because Japan is an 
archipelagic nation, and most people have been living or working in the port cities. Since the Meiji Restoration (1868), ports and harbours in Japan have been economic engines to promote regional economic development by developing industrial areas along the coast. It is worthy to note that about one quarter of Japanese coastline is under port jurisdiction [1].

Having gone through a period of remarkable economic growth, people started feeling that quality of life should be given more priority [2]. In 1985, Ports and Harbours Bureau of the Ministry of Transport announced a long-range port and harbour improvement policy "Ports and Harbours for the 21st Century". In this policy, "life-related function", which is defined in this study as port-based function to provide visitors with access to the ports, amenity and enjoyment at waterfront, was officially authorised as one of the basic port functions.

Based on this new policy, port planning works aiming at creation of lively atmosphere at inner harbours were implemented for many ports nationwide. "Port Renaissance 21" is a planning effort to introduce the life-related function to principal ports in Japan. This type of planning efforts has been made for a total of 59 port districts nationwide from 1985-1990 only.

Preceding studies state that 7 functional facilities such as commercial/service, business, passenger terminal, international/regional interchange, culture, amenity, marine recreation are introduced in many waterfronts [3]. The preceding studies contributed to show general information that life-related function and facilities were introduced into many ports and harbours in Japan. Little specific information, however, was given on what kinds of tourist resources, in particular, what kinds of local resources were utilised in each redevelopment projects at inner harbours. In my study local resources are defined as cultural or natural resources which exist in the study region and can be used for tourism promotion. Information on local resources is vital because tourism can generate only when differences exist between subjects and objects of tourist.

The purposes of this paper are following threefold:

(1) to make clear characteristics of port tourism;

(2) to identify the kinds and features of tourist resources and local resources which support portscape tourism;

(3) to examine sustainability of portscape tourism and its requirements.

The results reveal that many Japanese ports have been diversifying their functions to fulfil regional expectations by using local resources, but that they wait to be fully exploited for sustainable port space function.

\section{The history of port development in Japan}

The Edo Shogunate signed the Japan-US Treaty of Amity and Commerce, and accordingly opened 3 ports of Nagasaki, Hakodate, and Yokohama in 1859 when systematic seclusion policy terminated. A new political system was started in 1868 with the Emperor at the helm of the nation. In the early 1900s, ports in Japan strived for transforming from light industry-lead ports to heavy industry-dominated ports following the government's industry policy. Coastal 
industrial zone concept was proposed and implemented by business people at this stage of time.

The Port and Harbour Law was enacted in 1950, after the end of World War II. This legislation was a dramatic change concerning the construction, improvement, management, and operation of ports and harbours in Japan. This law clearly stated that ports were to be managed by port management bodies, which could be established by local government entities, not the national government.

Immediately after the war, Japan's economy began to recover. Japan's economic growth was led by mainly heavy and chemical industries. Ports were rapidly expanding terminals to cope with dramatic increases in cargos (fig. 1). These highly mechanized terminals were of such a huge scale that they had to be developed in segregated port areas away from city areas and peoples as a whole.

'Inner harbour' areas are used to be not only central places of the port but also birthplaces of most cities. Ports also started dividing their spatial structure into two parts: developing outer harbour areas for large-scale terminals and leaving obsolete and idle inner harbour areas. The rapid process of port modernization brought about serious disconnections, spatially and functionally, between ports and cities. In addition, people started feeling that more priority should be given to the quality of life rather than abundance of materials (Inoue [2], Murata and Kato [4]).

In 1985, a national port policy "Ports and Harbours for the $21^{\text {st }}$ Century" was formulated by the Ministry of Transport. In this new policy, ports are seen as a comprehensive space where three basic functions are combined: distribution, industrial, and life-related functions (fig. 2). This policy stressed a need to revitalize the inner harbours with a view to providing more amenities and a better quality of life to people. Port management bodies conducted 'Port Renaissance 21', 59 port districts nationwide during 1985-1990.

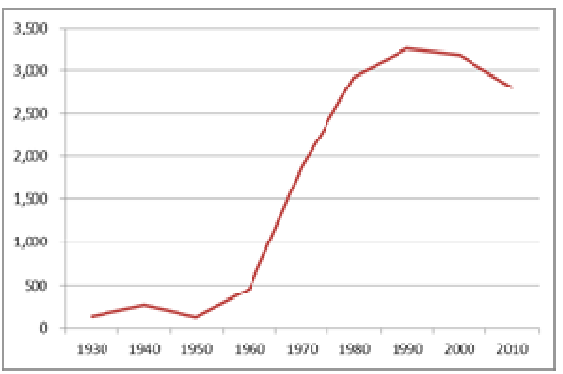

Figure 1: Port throughput. (Source: Annual Port Statistics.)

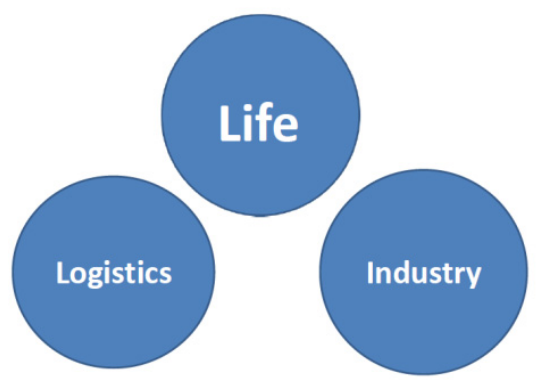

Figure 2: Main port functions. 


\section{Case studies}

\subsection{Methodology}

The following 5 port districts are carefully chosen as case study ports to be analysed. These ports should represent a variety of port types throughout Japan, and were selected among Port Renaissance 21 ports and other ports which have been actively engaged in creating "life-related function" in their ports [5]. Population size of hinterland city, geographical location, characteristics of port activities as well as degree of touristic activities is taken into considerations:

Yokohama: metropolis, central Japan, international, industrial;

Tokyo: metropolis, central Japan, international and domestic, container;

Aomori: $\quad$ medium size city, northern Japan, ferry port;

Kagoshima: medium size city, southern Japan, interisland shipping;

Mombetsu: small size city, northern Japan, fishery activities.

Figure 3 shows the locations of these 5 case study ports.

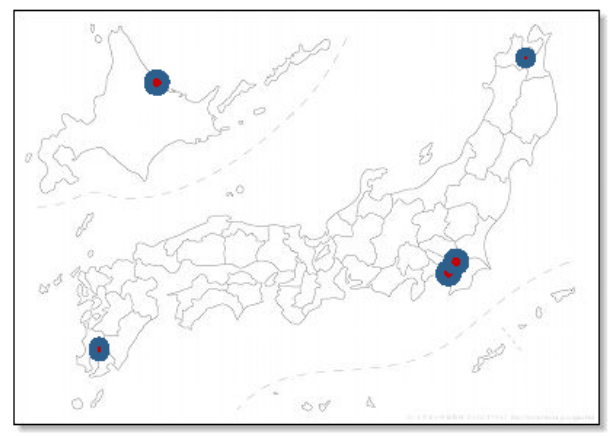

Figure 3: Location of the case study ports.

Table 1 shows both port activity indices and socioeconomic indices of hinterland cities. I visited these case study ports on site and confirmed the present situations of port facilities and their utilisation.

\subsubsection{Case study: The Port of Yokohama}

3.1.1.1 Outline of the Port of Yokohama Yokohama is situated $30-40 \mathrm{~km}$ away from Tokyo and is the $2^{\text {nd }}$ largest city in Japan, only after Tokyo. More than 3.6 million people live presently in the port city. Before the port was developed about 150 years ago, Yokohama was an isolated fishery hamlet where less than 100 houses were found (Horiguchi [6]).

The Port of Yokohama has been a leading port throughout the modernised age in Japan. The port handles a total of 121 million tons of cargo in 2011, and has been one of the leading international container ports. More than 3 million TEUs were registered in 2012. Port of Yokohama has also been No. 1 in cruising 
Table 1: $\quad$ Socioeconomic indices of 5 case study ports.

\begin{tabular}{|l|r|r|r|r|c|c|c|}
\hline & $\begin{array}{c}\text { (1)Throughput } \\
\text { (ton) }\end{array}$ & $\begin{array}{c}\text { (2)Population } \\
\text { (person) }\end{array}$ & $\begin{array}{c}\text { (3)Passenger } \\
\text { at port (person) }\end{array}$ & $\begin{array}{c}\text { (4)Port Visitor } \\
\text { (person) }\end{array}$ & $\begin{array}{c}\text { (5)Cruiseship } \\
\text { (calls in 2012) }\end{array}$ & $\begin{array}{c}\text { (6)Access } \\
\text { (km) }\end{array}$ & $\begin{array}{c}\text { (7)Site visit } \\
\text { by KATO }\end{array}$ \\
\hline Yokohama & $121,326,484$ & $3,605,951$ & 91,175 & $10,000,000$ & 142 & 0.9 & 17Aug2013 \\
\hline Tokyo & $73,903,748$ & $8,476,919$ & $1,517,014$ & $9,000,000$ & 28 & 7.2 & 03Nov2013 \\
\hline Aomori & $2,889,154$ & 306,263 & 315,662 & $1,160,000$ & 11 & 1.7 & 08Sep2013 \\
\hline Kagoshima & $6,137,963$ & 601,790 & $6,253,783$ & $2,000,000$ & 34 & 0.7 & 26Nov2012 \\
\hline Mombetsu & 274,428 & 25,248 & 61,934 & 36,000 & 0 & 2.7 & 31May2013 \\
\hline
\end{tabular}

Remarks;

(1) Port statistical yearbook 2011, Ministry of Land, Infrastructure, Transport and Tourism, Japanese government

(2) Ministry of Internal Affairs and Communications, Japanese government, Tokyo denotes central districts only.

(3) Port statistical yearbook 2011, Ministry of Land, Infrastructure, Transport and Tourism, Japanese government.

(4) The Ports and Harbours Association of Japan.

(5) Published from each municipality, figure in 2010

(6) Direct distance between port and city hall, measured based on Google Earth

(7) Dates surveyed by author

activities in Japan, and 142 cruise ship calls were recorded in 2012. More than 90,000 passengers embarked/disembarked at the port in 2011. In addition, coastal area has been extensively reclaimed after the World War II for use of heavy industries such as petroleum, chemical, steel and shipbuilding.

3.1.1.2 Zou-no-hana Kanagawa was specified as one the five open ports by the Japan-US Treaty of Amity and Commerce in 1858. The Port of Yokohama was opened in 1859 because Yokohama was a part of Kanagawa.

For opening of the port, 2 jetties were built near the present day Osambashi, which now accommodates international cruise vessels. In 1867 eastern jetty was extended and curved like a bow to prevent waves for cargo loading/unloading at the jetty. Because of this shape, the jetty is called Zou-no-hana (elephant nose in Japanese). Since the jetties were too shallow to all ships to dock, lighters were used to transport cargos between the oceangoing ships and the jetties [7].

3.1.1.3 Zou-no-hana Park Originally Zou-no-hana jetties were used for loading points for lighters as mentioned above. The jetties were crowded with export and import cargoes, and stevedoring people and merchants were busy on the jetties (fig. 4). After steel made wharf was built to the east of the Zou-nohana jetty and another wharf was built on newly reclaimed land to the west of the jetty, the Zou-no-hana jetty lost roles as the main player at the port of Yokohama, and used as berthing facility and basin for shallow draft barges.

Zou-no-hana was severely damaged and then subsequently rebuilt after the Great Kanto Earthquake in 1923. The Eastern Zou-no-hana Jetty gradually changed its shape age by age, and present one is based on the rebuilt shape after the Great Kanto Earthquake.

Zou-no-hana was opened to the public as a waterfront park on $2^{\text {nd }}$ June 2009 after the 150 years since the opening of the port of Yokohama. Zou-no-hana, where the port and city of Yokohama was born, transformed itself from where at one time being busy for cargo handling to where being public green space filled with open atmosphere. A total of more than 10 million people visited the redevelopment zone in the port of Yokohama annually (Figure 4(b)). 
The life span of port facilities is long and their functions change occasionally. It is important to look at facilities and their environment carefully to decide what is the most suitable utilization for them.

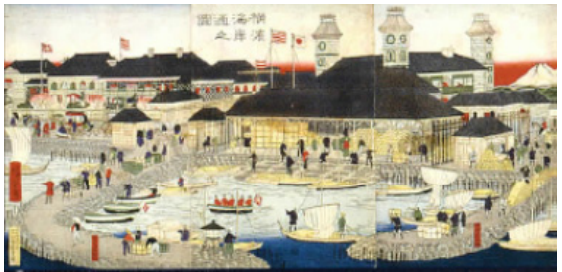

(a)

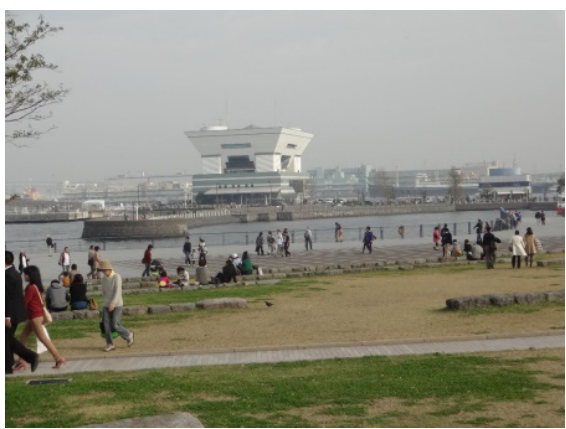

(b)

Figure 4: (a) Zou-no-hana in 1868; (b) Zou-no-hana in 2013 (courtesy of Yokohama Archives of History).

\subsubsection{Case study: Port of Tokyo}

3.1.2.1 Outline of the Port of Tokyo The Port of Tokyo has been servicing for the capital of Japan for more than 400 years. Presently Tokyo plays as one of the information centres for global economy. As of 2011 about 8.5 million people live in the 23 Special-ward areas only.

The port of Tokyo is situated at the innermost part of Tokyo Bay, and a marine area of 5,194 ha and a land area of 1,033 ha are designated as the port area and the waterfront zone of the port of Tokyo, respectively. Regarding containers, a total of 4,751,643 TEUs was registered in 2012 , i.e., by far the No. 1 container port in Japan. Number of passengers embarking/disembarking at the port of Tokyo is about 1.5 million, and 28 cruise ship calls are recorded in 2012.

3.1.2.2 Waste management Socioeconomic activities of Tokyo metropolis urge the port of Tokyo to bear a part of city functions in addition to the primary port logistic function (Shimizu [8]). Table 2 shows the historical change of waste dumping sites in the port of Tokyo. A total of 761 ha of port area (marine area) at seven locations of the port have been reclaimed for waste dumping sites since 1927, and a total of 101 million tons of waste have been dumped into them (fig. 5(a)).

3.1.2.3 Sea Forest The Inner Central Breakwater Reclamation Area has been reclaimed with 12,300,000 tons of waste generated in the 23 Special-ward areas during 1973-1987, and size of the area is approximately 88 ha, forming a hill with about 30 meter high above the sea level. 
Table 2: Historical change of dumping sites in the Port of Tokyo.

\begin{tabular}{|c|c|c|c|c|c|}
\hline \multirow[b]{2}{*}{ Site } & \multicolumn{2}{|c|}{ Area } & \multirow[b]{2}{*}{ Beginning } & \multirow[b]{2}{*}{ Completed } & \multirow[b]{2}{*}{ Waste (Ton) } \\
\hline & $\begin{array}{l}\text { Total Area } \\
\text { (m2) }\end{array}$ & $\begin{array}{l}\text { Reclaimed } \\
\text { Area }(\mathrm{m} 2)\end{array}$ & & & \\
\hline No. 8 Reclamation & 502,000 & 364,000 & 1927 & Dec. 1962 & $3,705,895$ \\
\hline No. 14 Reclamation & 457,860 & 450,810 & Dec. 1957 & Mar. 1967 & $10,336,246$ \\
\hline No. 15 Reclamation & 808,260 & 711,907 & Nov. 1965 & Nov. 1973 & $18,438,658$ \\
\hline Inner Central Breakwater & $1,060,000$ & 780,000 & Dec. 1973 & Mar. 1987 & $12,300,000$ \\
\hline Outer Central Breakwater & N.A & $1,990,000$ & 1977 & 2011 & $52,100,000$ \\
\hline Off Haneda Airport & N.A & 124,000 & 1984 & 1991 & $1,680,000$ \\
\hline New Sea Surface Deposit & N.A & $3,190,000$ & 1998 & - & $2,700,000$ \\
\hline
\end{tabular}

Source: Shimizu (1992) for No.8 Reclamation Inner Central Breakwater

http://www.kankyo.metro.tokyo.jp for Outer Central Breakwater $\sim$ New Sea Surface Deposit

"Sea Forest" is a name of the 30-year project to create a clean and green park on the Inner Central Breakwater Reclamation Area. "Sea Forest" aims at inheriting green and natural sea environment to next generations. Sea Forest fundraising campaign started to raise funds for tree planting activities, and planting seedlings at the site commenced in 2007. The project is targeting realisation of recyclable resources (fig. 5(b)) [9].

Tokyo Metropolitan Government expects that the large scale green wood which is afloat the port of Tokyo becomes a landmark of the national capital and constitutes one of the new resources for tourism in Tokyo. Actually this location is a good viewing spot to enjoy panoramic view of Tokyo waterfront including Sky Tree (World highest tower) and the Haneda airport. More than 9 million people visit the waterfront parks in the port of Tokyo annually.

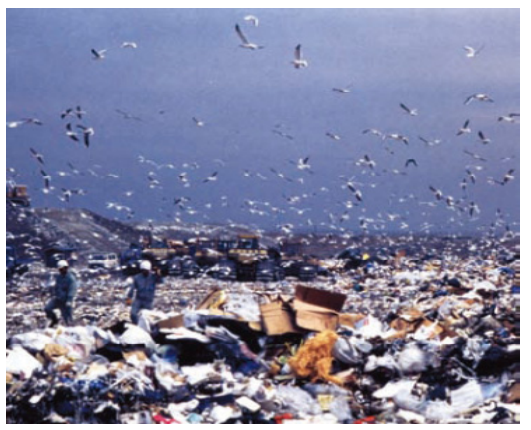

(a)

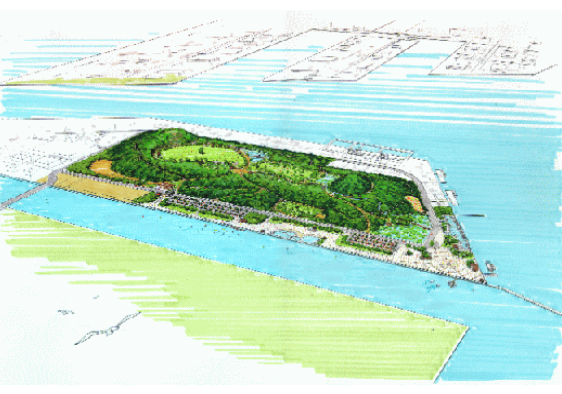

(b)

Figure 5: (a) Waste disposal site in c. 1994; (b) Sea Forest project (source: Tokyo Metropolitan Government web site).

\subsubsection{Case study: the Port of Aomori}

3.1.3.1 Outline of the Port of Aomori The Port of Aomori lies at the northernmost part of the Honshu, the largest island in Japan and designated as 
one of the major ports in Japan. Aomori City is the prefectural capital with a population of 306,263 in 2010 . Nearly 3 million tons of cargos except ferry cargo are loaded/unloaded at the port in 2011. Some 300,000 passengers embarked/disembarked in the same year.

The port of Aomori stands at the opposite side of Tsugaru Straits to the port of Hakodate. Seikan ferry had been plying between the ports of Aomori and Hakodate. Passengers and cargoes used to move between the 2 ports in cabins or wagons aboard the Seikan railway ferry. During the peak period, 8,553,033 tons of cargo and 4,985,695 passengers were recorded at the port of Aomori.

Operation of the Seikan ferry was ceased in 1988 when the world longest Seikan tunnel with $53.85 \mathrm{~km}$ in length was completed. Trains were able to run 1,000 meter below the sea bed between Aomori and Hakodate. The port of Aomori is no more a railway ferry terminal, but still functions as car ferry terminal although number of passengers dropped significantly.

3.1.3.2 Revitalisation of the waterfront Since the railway ferry terminal is adjacent to the urban centre, revitalization of the obsolete district was a must for the regional economy. First step to revitalise this district was to build a symbolic waterfront building called ASPAM (Aomori Sightseeing Products Mansion) which is 76 meter high and houses a variety of offices and shops including a theatre, information booth, conference facilities, and an observatory. More than 1 million tourists and citizens visit the ASPAM annually.

One of the railway ferries are permanently moored along a quay as a memorial ship museum, and a waterfront park with 4.6 ha in area and a $3 \mathrm{~m}$-wide promenade were developed near ASPAM. A museum for local culture and festival is also opened together with commercial facilities for tourist's convenience. Recent efforts by the public sector are to develop a viewing spot on the sea (Muramoto [10]).

3.1.3.3 Promenading breakwater A promenading breakwater was developed in the port of Aomori and opened to the public in April 2004. This breakwater is 310 meter in length and people can enjoy walking and jogging on the breakwater. Surface of the breakwater are made of wood or natural stones, and benches and observation decks are provided at the central parts on the breakwater. At the head of the breakwater, a corn-shaped white lighthouse is installed (fig. 6(a) and (b)).

A local resident gave the following comment: "Visiting citizens and tourists are usually surprised to know that views from the promenading breakwater are so good. Views from the sea are so fresh for people because we have little chance to enjoy views of towns and mountains from the sea while we had ample chances aboard the railway ferries when they ran" [11].

\subsubsection{Case study: the Port of Kagoshima}

3.1.4.1 Outline of the Port of Kagoshima The Port of Kagoshima is housed in the prefectural capital of Kagoshima City with population of 601,790 in 2010. The port handled more than 6 million tons of cargoes, and chemical products are main commodities. 


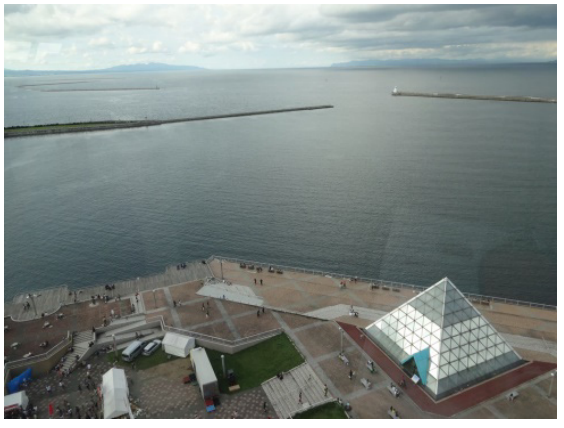

(a)

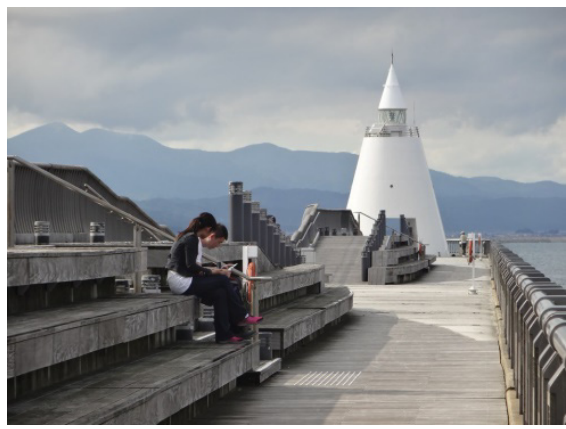

(b)

Figure 6: (a) View from ASPAM observatory; (b) Promenading breakwater.

The Port of Kagoshima has been a maritime traffic hub for surrounding regions and islands. In addition, ferry services between the Honko-district and the port of Sakurajma have been provided. The latter is only $3.5 \mathrm{~km}$ away from the former, and ferry boats can transport cars and passengers by 15 minutes. The ferry has been servicing for 24 hours, and more than 6 million passengers use the ferries annually.

3.1.4.2 Old stone breakwaters In 1602 the Shimazu clan moved their residence to Tsurumaru Castle, which was built close to seashore. Area on the Kagoshima castle town was gradually expanded by reclaiming shore land. According to an old illustration drawn in 1843, several breakwaters and dikes had already been built to protect the castle town from high waves (fig. 7(a)).

Some of these stone breakwaters were demolished due to port expansion works or natural disasters by early or middle of the $20^{\text {th }}$ century. According to records, Nabeya gangi (gangi means quay in old Japanese), which was built in c. 1780, was the oldest among them. It is pointed out that construction of the stone breakwaters and quays at Kagoshima was the largest port construction works during the Edo period because these old port facilities were about $14-15 \mathrm{~m}$ deep. Even compared with other nations, the Kagoshima's port construction works is the world largest class at that time (Shimazaki [12]).

3.1.4.3 Original port plan As rapid economic growth continued during the 1960s and 1980s, the port of Kagoshima needed more space for cargo handling. Prefectural government formulated a long-term development plan of the port of Kagoshima in 1982. The new plan aimed at strengthening cargo handling function.

Only Shin-hashi and Iccho-daida breakwaters remained when the World War II ended, but the new port plan could not avoid negative impact to the historical port facilities. The Shin-hashi breakwater had to be partially cut off to create a new channel and the Iccho-daida breakwater was supposed to be reclaimed to create a land area. According to the new port plan, only top of the stone breakwaters will be visible on the reclaimed area.

Kagoshima Junior Chamber of Commerce expected that redevelopment of the Honko district could revitalise the local economy, and held Waterfront Festival 
in 1988 to attract people to waterfront. Tens-thousand citizens gathered at the waterfront and enjoyed fresh views and atmosphere at the waterfront. This festival initiated citizen's awareness about the waterfront and port.

3.1.4.4 Revised port plan The Shin-hashi breakwater had been covered with concrete to maintain structural strength. Therefore people considered that aesthetical value of this old port facility was little although historical value maintained. The port management body in 1993 uncovered the concrete in trial and found that surface of stone-made breakwater appeared complete and unhurt (Saito [13]).

The long-term port plan was revised so that surfaces of both the Shin-hashi breakwater and Iccho-daiba breakwater could be seen on sea from town side. Now Kagoshima's port heritage is easily shared by citizens and visitors who come to the Honko-district (fig. 7(b)).

The historical stone breakwater is a nucleus of local resources for port tourism. An aquarium and wooden promenades were built along the old stone breakwaters. More than 2 million people are visiting the inner harbour for shopping, eating and relaxing. People enjoy views of ferries passing nearby.

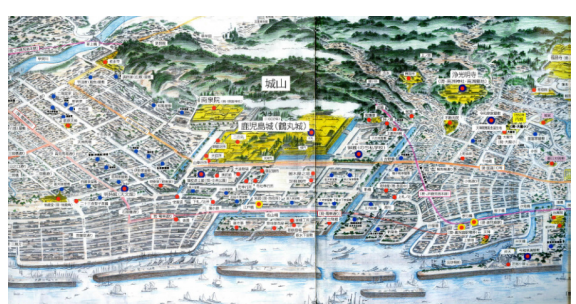

(a)

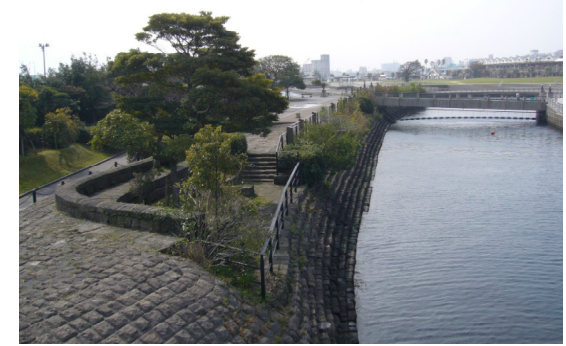

(b)

Figure 7: $\quad$ (a) Kagoshima castle town (1843); (b) Iccho-daiba (2012). (Source: NPO Yume Minato Kagoshima.)

\subsubsection{Case study: the Port of Mombetsu}

3.1.5.1 Outline of the Port of Mombetsu Mombetsu is located at lat. $44^{\circ} \mathrm{N}$, which is far south of London (lat. $51^{\circ} \mathrm{N}$ ). Mombetsu sits on the almost centre of the Okhotsk coast which is the southern limit of drifting sea ice observation. During a harsh winter it comes ashore.

The port was designated as an important port in 1975 and as an open port in 1980. The port has been functioning mainly as a base for fishing activities as well as cargo transport for hinterland. A total of 61,934 passengers embarked /disembarked at the port in 2011.

3.1.5.2 International city for drifting sea ice research Mombetsu city has a population of about 30,000, and fishing has been a main industry for the city economy. Drifting sea ice comes ashore every January or February from the northern Sea of Okhotsk. Boats have to be lifted to land, and the city's marine 
activities are stopped and locked completely. The drifting sea ice has been considered and treated as a nuisance.

Leaders of the city realized that living together with drifting sea ice is a healthy choice and that drifting sea ice itself should be treated as one of the resources which the city exploits. In 1990 the city set up a long-term plan to aim at "International city for drifting sea ice research." Even before the City's long term plan, Hokkaido University had established a research facility on drifting sea ice at Mombetsu City, and a private shipbuilding company carried out field experiments on ice pressure and development of an ice breaker vessel (Archimedean screw-type) for tourists. International symposium on the Sea of Okhotsk and drifting sea ice was held in 1986 in Mombetsu. This annual symposiums have been collaborative works among academy, administration and civic volunteer groups.

3.1.5.3 Okhotsk Tower and promenading breakwater Okhotsk Tower was built in 1996 to serve as an academic research centre on drifting sea ice studies at 40 meter off the head of No. 3 breakwater. The tower is 38.5 meter high above the sea level and 7.5 meter low below the sea level. Total floor area is $2,344 \mathrm{~m}^{2}$. The tower is composed of 3 floors above the sea level and an additional underwater observatory, which is the world's $1^{\text {st }}$ underwater observatory in the ice sea. The tower has another function, i.e., to promote tourism in the Okhotsk region, particularly in the city of Mombetsu. Citizens and tourists can look at ecologies under iced sea during winter (Saeki [14]).

No. 3 breakwater is 515 meter long and 12.5 meter wide, and is designed as a promenade on sea with triple deck structure. The 50 meter section of head of the breakwater is widen to 30 meter and is connected to the Okhotsk Tower. People can walk on the top of the breakwater and get into the tower where panoramic views are provided on the upper floor. Both tower and breakwater became popular viewing spots for drifting sea ice on the Sea of Okhotsk.

More than 160,000 visitors were admitted at the Okhotsk Tower in the $1^{\text {st }}$ year of opening. Figs 8(a) and (b) show the Okhotsk Tower, breakwater and ice breaker.

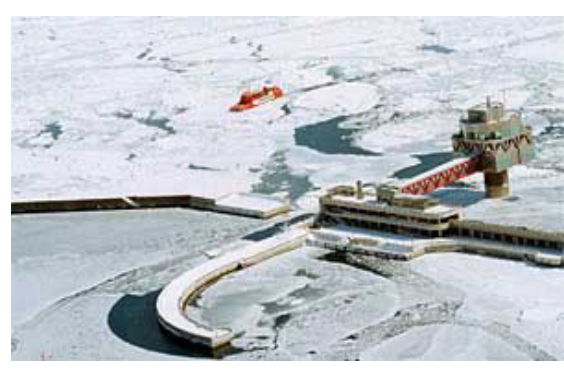

(a)

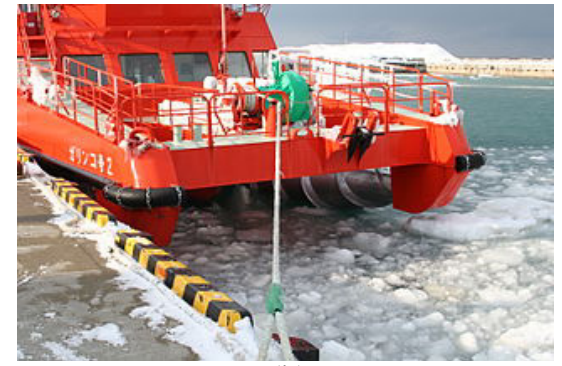

(b)

Figure 8: (a) Okhotsk Tower and breakwater; (b) Ice breaker vessel (source: [15]). 


\section{Conclusion}

Conclusions derived from this study can be summarised as follows

(1) Ports have been regarded as traffic nodes for tourists who embark/disembark at ports and depart for their destinations. In tourism ports also play a role as tourist attractions. This study reveals that in many ports the number of people who visit them as tourists exceeds the number of passengers who use them as traffic nodes.

(2) This study suggested that ports are attracting tourists using local resources. Port heritage, large open spaces in the port, good location for enjoying the portscape, and natural resources are identified as local resources for port tourism in the case studies.

- Port facilities have potentially multiple functions, and transform from one to another, reflecting needs of hinterland for a long run.

- Vastness of port space is potential resources for port tourism. Underwater space was used as waste disposal site, then changes to a tourist landmark.

- A breakwater head is a superb viewing spot on sea where people can enjoy a port view, a townscape and a mountain range.

- Historical stone breakwater appeared unhurt when capped concrete was uncovered. Citizens awareness helped preserve and create their heritage.

- Drifting sea ice, which had been nuisance, became tourist attractions along the Sea of Okhotsk. Recognition of locality creates tourist value.

(3) In general local resources are being utilised effectively to promote port tourism in many case studies. On the other hand, however, it is difficult by nature for local residents to be awakened to the importance of the local resources. Therefore, collaboration is necessary between local residents and people who live outside the regions for sustainable port tourism.

\subsection{Suggested further studies}

It is suggested that further studies should be applied by other countries, climate, culture, and types of port functions such as river ports and canal ports. Related papers will surely contribute to the portscape tourism and sustainable port space function.

The study reveals that many ports have been expanding their functions to fulfil regional expectations by using local resources, however they are yet to be exploited for other sustainable port space functions in Japan. 


\section{References}

[1] The ports and harbours association of Japan, ed., Japanese ports in figures (in Japanese), The ports and harbours association of Japan, pp. 200-201, 2013.

[2] Inoue, S., Basic framework for integrated port space planning (in Japanese), Doctoral dissertation, 1992.

[3] The ports and harbours association of Japan, ed., History of Japanese ports and harbours (in Japanese), Seizando-shoten publishing co. Ltd., 2007.

[4] Murata, T. \& Kato, H., The history of port development and its future extension, Japan technical session, 27th International navigation congress, 1990.

[5] Waterfront revitalization research center, Japan, A synopsis yearbook of waterfront revitalization studies (in Japanese), Waterfront revitalization research center, Japan, 1990-96.

[6] Horiguchi, T., Port of Yokohama - from birth to today (in Japanese), Journal of the Japan society of civil engineers, 57 (4), pp. 97-104, 1972.

[7] Planning and Coordination Bureau, the City of Yokohama, Development process of port city Yokohama (in Japanese), pp. 015- 035, 1981.

[8] Shimizu, K., Development of port of Tokyo and its history (in Japanese), The association for the geological collaboration in Japan, No. 28, pp. 1118, 1997.

[9] Umi-no-mori (Sea Forest), Tokyo metropolitan government, Bureau of port and harbor, Marine parks section web site, retrieved 08 November 2013 from http://www.uminomori.metro.tokyo.jp/index_e.html

[10] Muramoto, S., Aomori port: rediscovery of my home town port (in Japanese), Port and harbour, 87(12), pp. 54-56, 2010.

[11] Japan dredging and reclamation engineering association, Aomori port (in Japanese), Marine voice 21, retrieved 26 December 2013 from http://www. umeshunkyo.or. jp/202/248/data.html

[12] Shimazaki, T., Roles of ports in modern society (in Japanese), Centennial symposium report on port city Kagoshima, NPO Yume Minato Kagoshima, pp. 7-9, 2007.

[13] Saito, U., Selected cases for civic design (category of ports) (in Japanese), Japan society of civil engineers, retrieved 08 November 2013 from http://www.nilim.go.jp /lab/bcg/siryou/tnn/tnn0434pdf/ks043407.pdf

[14] Saeki, H., The unique facility of sea ice observation on the bottom of Okhotsk Sea (in Japanese), Journal of the Japan society of civil engineers, 81(1), pp. 2-5, 1995.

[15] Hokkaido regional development bureau, Mombetsu port office web site (in Japanese),http://www.ab.hkd.mlit.go.jp/kouwan/monbetsuport/information /index.html, retrieved on 18 November 2013. 